\title{
MEMBEDAH SERVANT LEADERSHIP PERSONAL KEFARMASIAN (Sebuah Studi Kasus Apoteker PT. Kimia Farma Apotek UB Semarang)
}

\author{
Ita Zonia Wisudasari¹, Fuad Mas'ud², Eddy Rahardja ${ }^{3}$ \\ ${ }^{1}$ Magister Manajemen, Fakultas Ekonomika dan Bisnis, Universitas Diponegoro \\ 2 Magister Manajemen, Fakultas Ekonomika dan Bisnis, Universitas Diponegoro \\ ${ }^{3}$ Magister Manajemen, Fakultas Ekonomika dan Bisnis, Universitas Diponegoro
}

\begin{abstract}
The purpose of this research is to analyze the characteristics of servant leadership and servant leadership competence conducted Apothecary built by the Apothecary at PT. Kimia Farma UB Semarang.From this research is expected to contribute the development of science in general and the field of human resources management in particular and as a reference when further research is conducted, especially on those who want to learn about servant leadership.Another goal is that management is expected to use as a material consideration or input to PT. Kimia Farma UB Semarang as a guide in competition Pharmacist to have leadership servant leadership that synergize with profession

The participants of this research consisted of 10 people, consisting of 7 (seven) person Apothecary and 3 (three) Apothecary Assistant. The ten participants representing structural position of PT. Kimia Farma UB Semarang. Determination of informants using snowball sampling method. This research method is qualitative analysis tool used is the technique of triangulation and member check.

The result of the analysis showed that all participants of PT. Kimia Farma UB Semarang proved the characteristics of servant leadership and servant leadership competence can be built by the pharmacist. Expected Pharmacist as a leader able to build a communication that can synergize existing resources to maximize the potential of subordinates to be successful
\end{abstract}

Key Words : Servant Leadership, Pharmacist, Qualitative Research.

\section{PENDAHULUAN}

Tenaga kefarmasian adalah tenaga yang melakukan sebuah pekerjaan kefarmasian, yang terdiri dari Apoteker dan tenaga teknis kefarmasian meliputi asisten apoteker. Pekerjaan kefarmasian merupakan pekerjaan termasuk pengendalian mutu sediaan farmasi, pengamanan, pengadaan, penyimapanan dan pendistribusian obat, pengelolaan obat yang benar, pelayanan obat atas resep yang diberikan oleh dokter, pelayanan informasi obat serta pengembangan bahan obat (PP RI No. 51,
2009). Apoteker adalah sarjana farmasi yang telah lulus sebagai apoteker dan tekah mengucpkan sumpah jabatan apoteker (Permenkes RI No. 35, 2014).

Apoteker merupakan posisi kunci dalam mencegah penggunaan obat yang tidak tepat, penyalahgunaan obat dan penulisan resep yang tidak rasional, misalnya dosis yang diberikan tidak lazim, tidak sesuai dengan usia atau berat badan pasien. Apoteker untuk mewujudkan kinerja yang handal dan terlatih sangat dibutuhkan jiwa kepemimpinan, yaitu 
kepemimpinan yang melayani (servant leadership).

Kepemimpinan pelayan merupakan pendekatan jangka panjang yang mampu memberikan perubahan yang baik bagi kehidupan dan pekerjaan. Suatu cara mempunyai peluang untuk menciptakan perubahan yang positif dan akan mempengaruhi kehidupan dalam lingkungan. Konsep kepemimpinan pelayan ini lebih menonjolkan pelayanan kepada orang lain atau lebih tepatnya kepada anak buah, akan semakin menumbuhkan keterikatan yang kuat antara pemimpin dengan anak buah.

Pada penelitian ini, akan dilakukan penelitian mengenai membedah servant leadership profesi Apoteker di PT. Kimia Farma Apotek Unit Bisnis Semarang. Keberhasilan suatu organisasi atau perusahaan sangat dipengaruhi oleh kinerja pegawainya. Terlebih pada organisasi yang bertugas melayani kebutuhan masyarakat sesuai dengan bidangnya dalam hal ini di bidang kesehatan. Salah satu Badan Usaha Milik Negara (BUMN) yang bertugas melayani kebutuhan masyarakat di Kota Semarang dalam bidang kesehatan yaitu PT. Kimia Farma Apotek Unit Bisnis Semarang (PT. KFA UB Semarang).

PT. Kimia Farma Apotek Unit Bisnis Semarang demi menjalankan peranan yang maksimal pada, dibutuhkan kinerja yang maksimal pula dari para pegawai yang bekerja di dalamnya. Penelitian mengenai membedah servant leadership sangat penting dalam suatu organisasi yaitu pada PT. Kimia Farma Unit Bisnis Semarang belum pernah diadakan penelitian mengenai servant leadership pada profesi Apoteker.

Berdasarkan pendahuluan tersebut dapat didentifikasi tujuan dalam penelitian ini sebagai berikut:

1) Menganalisis karakteristik servant leadership yang dibangun oleh Apoteker di PT. Kimia Farma Unit Bisnis Semarang.

2) Menganalisis kompetensi servant leadership yang dilakukan Apoteker di PT. Kimia Farma Unit Bisnis Semarang.

3) Menganalisis pelaksanaan dan penerimaan servant leadership dari Apoteker kepada anak buahya di PT. Kimia Farma Unit Bisnis Semarang.

\section{TELAAH PUSTAKA DAN PENGEMBANGAN MODEL PENELITIAN}

\section{Telaah Pustaka}

Servant Leader adalah merupakan kegiatan melayani yang pertama kali harus dilakukan. Diawali dengan perasaan bahwa jika seseorang ingin dilayani maka ia harus melayani terlebih dahulu, kemudian pilihan yang dilakukan dengan bercita-cita tinggi untuk menjadi pimpinan. Orang tersebut sangat berbeda dengan pimpinan sebelumnya, mungkin karena adanya keharusan memiliki sesuatu yang bersifat material. Tipe "pemimpin" yang pertama dan tipe "pelayan" yang merupakan dua hal yang sangat berbeda, diantara keduanya terdapat gabungan variasi sifat manusia yang tak terbatas (Greenleaf, 1970). Jika Servant Leadership diaplikasikan pada organisasi, maka akan berdampak pada perilaku pemimpin, yang akan mempengaruhi anak buahnya.

Servant leader adalah sosok pemimpin yang mengutamakan kebutuhan pengikut, aspirasi dan kepentingan pengikutnya diatas kepentingan mereka sendiri, pemimpin yang berkomitmen untuk melayani anak buahnya, hal tersebut dikemukakan oleh Sendjaya dan Saros (2002). Sedangkan, Trompenaars dan Voerman (2010) mengemukakan gaya manajemen dalam hal memimpin dan melayani berada dalam satu irama yang selaras dan terdapat interaksi dengan 
lingkungan organisasi merupakan pengertian servant leadership.

Dimensi Servant Leadership yang dipaparkan oleh Patterson, 2003, seorang servant leader adalah pemandu didalam hal kebaikan. Seorang pengikut menggambarkan pimpinan pada bentuk sikap, karakteristik dan perilaku. Seorang pemimpin yang melayani mampu membangun:

1) Kasih Sayang (Love)

2) Pemberdayaan (Empowerment)

3) Visi (Vision)

4) Kerendahan Hati (Humility)

5) Kepercayaan (Trust)

6) Mementingkan kepentingan orang lain (Altruism)

7) Pelayanan (Service)

Seseorang yang ingin menjadi seorang pelayan yang baik, maka seorang pemimpin mampu memiliki karakter pelayan menurut Spears, 2010: Listening, Empathy (empati), Awareness (kepedulian), dan Building community (membangun komunitas).

\section{Kerangka Pemikiran Penelitian}

Seorang pemimpin yang melayani mampu membangun dimensi melayani dengan: kasih, kerendahan hati, mendahulukan kepentingan umum, memiliki rencana ke depan untuk bawahan yaitu sejenis visi yang mampu meningkatkan sifat kepemimpinan dari bawahan, kepercayaan yang wajib ditanamkan kepada bawahan dengan meyakinkan baha perusahaan ini bukanlah milik pemimpin atau milik stakeholder, melainkan yakinkan bawahan bahwa perusahaan yang digunakan sebagai tempat bekerja sekarang merupakan perusahaan sendiri, melakukan pemberdayaan karyawan dalam hal interaksi positif antara pimpinan dengan bawahan dan melayani dengan sepenuh hati.

Keseluruhannya, dapat disimpulkan pemimpin yang melayani ini bersifat gentle dan berbelas kasih, menunjukan kekuatan dan control diri, berlaku tenang dan damai di tengah kekacauan, pemimpin akan menenangkan ketika yang lain berkonfrontasi dengan kemarahan dan berperilaku bijaksana, ramah yang menginspirasi lainnya untuk mempertahankan harga diri dan martabat mereka.

Jika karakteristik servant leadership ini menjadi dasar diri Apoteker maka hal ini akan menghasilkan hasil positif perusahaan. Servant leadership merupakan asumsi bersama yang dipelajari oleh suatu kelompok dalam memecahkan masalah, sehingga dapat diajarkan dan diterapkan kepada anggota baru sebagai cara yang benar untuk melihat, berpikir, dan merasakan kaitannya dengan masalah-masalah yang ada.

Dari hasil telaah pustaka dan analisis terhadap bukti bukti nyata dari penelitian terdahulu, maka kerangka pemikiran yang dikembangkan untuk diteliti dan dalam penelitian ini disajikan dalam gambar berikut ini: 


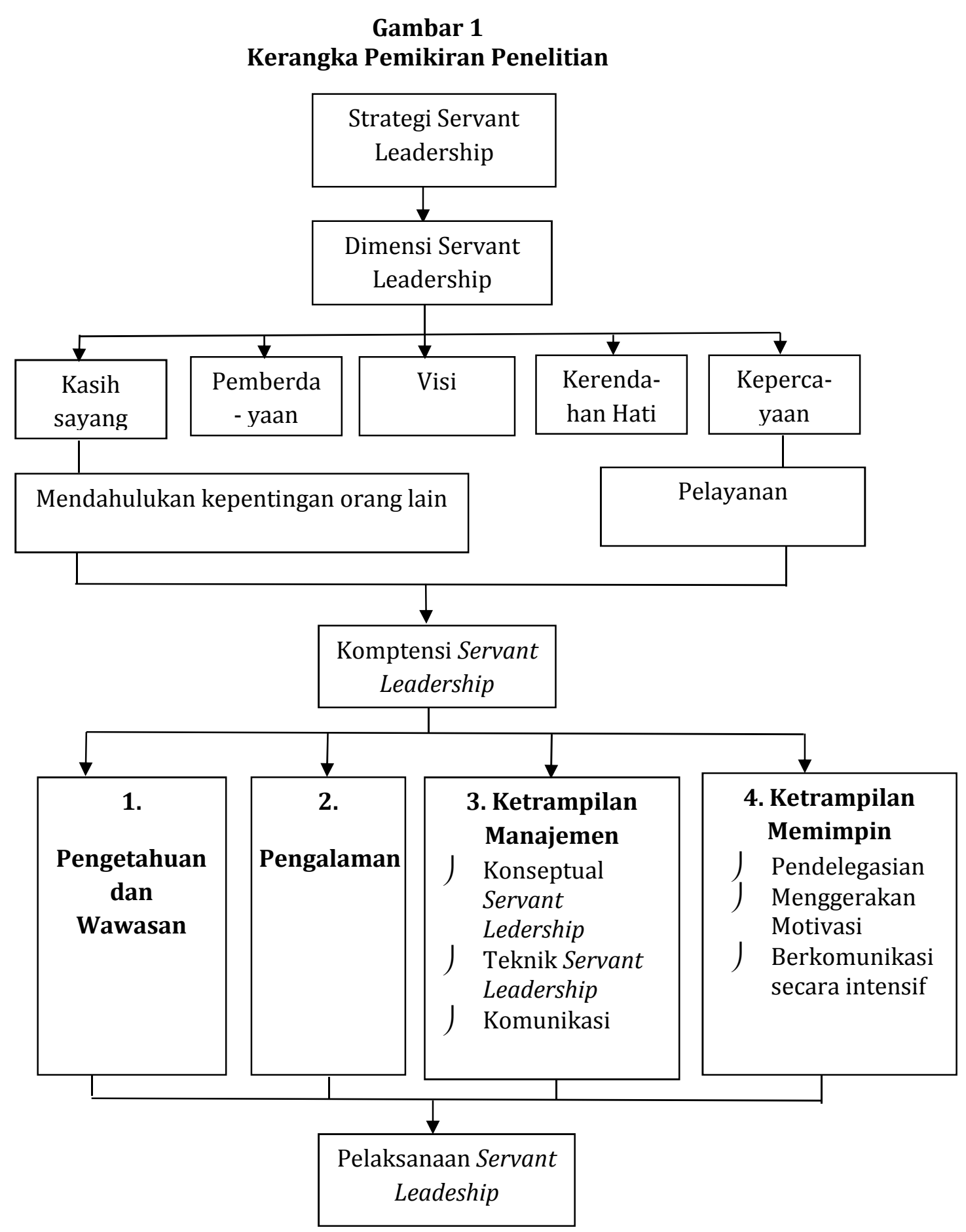

\section{METODE PENELITIAN}

Penelitian ini menggunakan jenis penelitian kualitatif dengan analisis deskriptif. Penelitian dengan menggunakan metode kualitatif adalah suatu proses penelitian dan pemahaman yang menyelidiki suatu fenomena sosial dan masalah manusia. Metode penelitian kualitatif digunakan karena dapat melihat bagaimana proses terbentuknya pemaknaan dan tindakan 
orang-orang yang ada di dalam dunia tersebut (Yin, 2009).

Studi kasus merupakan metode pendekatan yang digunakan untuk penelitian ini. Studi kasus merupakan salah satu jenis pendekatan kualitatif yang menelaah sebuah "kasus" tertentu dalam konteks atau setting kehidupan nyata kontemporer. Penelitian studi kasus adalah pendekatan kualitatif yang penelitinya mengeksplorasi kehidupan nyata, sistem terbatas kontemporer (kasus) atau beragam sistem terbatas (berbagai kasus), melalui pengumpulan data yang detail dan mendalam yang melibatkan beragam sumber informasi atau sumber informasi majemuk (misalnya, pengamatan, wawancara, bahan audiovisual, dan dokumen dan berbagai laporan) (Creswell, 2015)

Penelitian ini akan dilakukan di 10 (sepuluh) titik outlet PT. Kimia Farma Apotek Unit Bisnis Semarang.

Satu langkah yang terkait erat dalam proses tersebut adalah menentukan strategi untuk sampling individu atau tempat. Sampling ini bukanlah sampel probabilitas yang akan memungkinkan seorang peneliti untuk menentukan kesimpulan statistik pada populasi; tetapi, sampel ini adalah sampel purposeful yang akan mencontohkan kelompok masyarakat yang dapat memberikan informasi terbaik pada peneliti tentang permasalahan riset yang sedang dipelajari (Cresswell, 2015).

Data disetiap penelitian, selain menggunakan metode yang tepat juga diperlukan memilih metode pengumpulan data yang relevan, karena data merupakan faktor penting dalam penelitian, maka sumber yang digunakan: data yang diperoleh langsung dari informan melalui kegiatan wawancara. Dalam menetapkan data ini, informan menggunakan teknik snowball sampling. Snowball sampling merupakan teknik pengambilan sampel dengan bantuan key-informan, dan dari key-informan tersebut yang akan berkembang sesuai petunjuknya. Dalam hal ini peneliti mengungkapkan kriteria sebagai persyaratan untuk dijadikan sampel (Molleong, 2010)

Dengan teknik snowball sampling ini dipilih Apoteker Penanggung Jawab berjumlah satu orang, yang akan menjadi key-informan untuk selanjutnya memberikan petunjuk siapa informan Apoteker Penanggung Jawab dan Asisten Apoteker yang berkompeten dalam memberikan data.

Data yang diperoleh dari pengumpulan data yang menunjang data primer, data sekunder ini adalah dokumentasi yang berkaitan dengan penelitian ini. Data untuk keperluan studi kasus bisa berasal dari enam sumber, yaitu: dokumen, rekaman arspi, wawancara, pengamatan langsung, observasi partisipan, dan perangkat-perangkat fisik (Yin, 2009).

Subyektivitas peneliti merupakan hal yang dominan dalam penelitian kualitatif dengan alat penelitian yang diandalkan adalah wawancara dan observasi. Alat penelitian ini mengandung banyak kelemahan ketika dilakukakn secara terbuka dan tanpa kontrol. Sumber data kualitatif yang kurang kredible akan mempengaruhi hasil akurasi penelitian. Oleh karena itu, dibutuhkan beberapa cara menentukan keabsahan data yaitu:

1) Kredibilitas

2) Transferabilitas

3) Dependability

4) Konfirmabilitas

Hal ini dilakukan dengan membicarakan hasil penelitian dengan orang yang tidak dilakukan dengan membicarakan hasil penelitian dengan orang yang tidak ikut dan berkepntingan dalam penelitian dengan tujuan agar hasil dapat lebih obyektif.

Dalam penelitian ini pengujian kebasahan/validitas data, peneliti 
menekankan pada uji kredibilitas member check yaitu proses pengecekan data dengan mendatangi kembali informan setelah merangkum atau mendiskripsikan data-data yang telah diberikan, atau melalui diskusi dengan teman sejawat terkait dengan data yang diperoleh (Molleong, 2007).

\section{PEMBAHASAN}

Ciri khas kepemimpinan pelayan bukanlah suatu harga mati, yang terpenting bahwa kepemimpinan pelayan itu dimulai dari diri sendiri, artinya seorang pemimpin dapat melaksanakan kepemimpinan pelayan jika ada semangat tulus dari dalam dirinya untuk menjadi yang terdepan dalam pelayanan.

Melayani pihak lain berarti dimana pemimpin memfasilitasi bawahannya untuk mencapai tujuan yang diharapkannya, nilai dasar dari karakteristik servant leadership diantaranya: kerendahan hati, mengutamakan orang lain dan pelayanan, sedangkan tindakan dari karakteristik servant leadership yaitu memiliki visi, pemberdayaan dan percaya.

Dari hasil analisis data didapatkan bahwa partisipan menyebutkan karakteristik yang paling penting menurut partisipan yaitu karakteristik servant leadership dimensi rendah hati, seperti uraian dibawah ini:

\section{Kasih sayang}

Kasih sayang ini menyebabkan pemimpin untuk menganggap setiap orang tidak hanya sebagai alat untuk mencapai tujuan, tetapi sebagai orang pelengkap antara kebutuhan dan keinginan, pemimpin yang mampu membuat pengikutnya merasa pribadi yang penting, bukan sekedar sebagai bawahan namun sebagai teman yang akan siap membantu bukan berdasarkan alasan pekerjaan.
Sesuai dengan teori Patterson, yaitu kepemimpinan yang mengasihi dengan cinta yaitu pemimpin mampu melakukan tindakan yang benar pada waktu tepat untuk mendapatkan keputusan terbaik bagi anak buah.

\section{Rendah hati}

Kerendahan hati bukan berarti memiliki rendahnya pandangan terhadap diri sendiri atau nilai diri seseorang, melainkan berarti melihat seseorang tidak lebih baik atau buruk daripada yang lainnya, sesorang pemimpin yang bangga dengan prestasi anak buahnya. Prestasi yang didapatkan anak buahnya ini didapatkan dari koordinasi dan komunikasi yang dibangun baik oleh pemimpin dan anak buah.

Pribadi yang mempunyai sifat rendah hati biasanya memandang bahwa orang lain sama sebagai ciptaan Tuhan yang memiliki keunikan dan keistimewaan masing-masing, jadi dia akan senantiasa membuat orang lain menjadi merasa penting dalam kehidupannya.

Setiap orang adalah special, unik, serta berhak untuk dihargai, setiap manusia didunia ini adalah pribadi yang harus diperlakukan khusus dan tidak dibedabedakan, karena manusia juga adalah makhluk yang sensitif. Hal ini sesuai dengan yang dituliskan Patterson, dengan menunjukkan rasa hormat dan mengakui keterlibatan anak buah dalam team merupakan sosok pemimpin yang rendah hati.

\section{Mengutamakan Orang Lain}

Mengutamakan orang lain yaitu mementingkan kebutuhan orang lain, yaitu kebutuhan pengikut, seperti mensejahterakan anak buahnya, kebijakankebijakan banyak diberikan oleh pemimpin demi mensejahterakan karyawanya. 
Sebagai pemimpin mampu mengutamakan orang lain diatas dirinya sendiri, merupakan sosok pemimpin dengan kualitas individu yang baik, menurut Kaplan dan Monroe, walau pemimpin dengan kualitas individu yang baik ini terkadang akan merepotkan dirinya sendiri.

Sosok pemimpin idola adalah pemimpin yang mampu membantu dan memberikan perhatian kepada anak buahnya, pemimpin inilah yang mampu mensejahterakan anak buahnya, dan akan buahnya pun akan dengan senang hati mengikuti apa yang telah menjadi tujuan pemimpinya.

\section{Visi}

Visi adalah pandangan jauh tentang suatu perusahaan, visi juga dapat di artikan sebagai tujuan perusahaan atau lembaga dan apa yang harus dilakukan untuk mencapai tujuannya tersebut pada masa yang akan datang atau masa depan.

Visi dari PT. Kimia Farma sendiri yaitu Menjadi korporasi bidang kesehatan terintegrasi dan mampu menghasilkan pertumbuhan nilai yang berkesinambungan melalui konfigurasi dan koordinasi bisnis yang sinergis, dengan pembagian job desk yang sesuai maka target perusahaan akan mudah dicapai.

Sesuai dengan teori Patterson yang menyebutkan bahwa visi yang akan membawa arah organisasi di masa depan dan pemimpin sebagai aspirator serta membantu mewujudkan visi perusahaan.

\section{Kepercayaan}

Percaya adalah karakterisitk terpenting dalam servant leadership, pemimpin melakukan apa yang dikatakan, yang menimbulkan kepercayaan, keterbukaan seorang pemimpin untuk menerima masukan dari orang lain meningkatkan kepercayaan pada seorang pemimpin.
Kepercayaan menjadi hal terpenting, pengikut lebih cenderung mengikuti pemimpin dengan perilaku yang konsisten, dapat dipercaya dan dapat langsung terhubung dengan aspirasi pengikutnya.

Kepercayaan dalam dunia kerja menjadi kunci terpenting, karena jika sudah tidak ada lagi kepercayaan dalam dunia kerja, maka tujuan perusahaan yang sudah disusun dengan rapi, dijamin tidak akan tercapai.

\section{Pemberdayaan}

Pemberdayaan adalah mempercayakan kepada orang lain, menyangkut membuat orang merasa penting dan menempatkan penekanan pada kerja sama tim. Pemberdayaan anak buah oleh pimpinan sesuai dengan kemampuan yang dimiliki oleh anak buahnya.

Masing-masing anak buah memiliki ketrampilan yang berbeda, ketrampilan yang berbeda, pemberdayaan pun akan mengikuti sesuai ketrampilan, dengan pelatihan yang berkesinambungan dan pembagian team fokus, akan memudahkan pemimpin untuk mencapai tujuan perusahaan.

Penunjukan team fokus ini berdasarkan dari pendapat dari anak buah atau antar team, karena komunikasi yang terjalin dapat menyiratkan saran kepada pimpinan untuk penunjukan team fokus, seperti teori Patterson, yaitu penekanan pada kerjasama yaitu mempercayakan kekuasaan pada orang lain, dan mendengarkan saran dari followers. Tim fokus yang dibentuk di BM Semarang ini ada team fokus marketing dan komunikasi, GPP (Good Practice Pharmacy), merchandising dan sumber daya manusia.

\section{Pelayan}

Pelayan adalah segalanya, pemimpin untuk melayani orang lain, harus memiliki rasa tanggung jawab. Pelayan adalah sosok yang mampu menempatkan diri sebagai 
orang lain, bisa memposisikan diri sebagai orang lain dan seolah-olah bisa ikut merasakan apa yang dialami oleh orang lain.

Kemampuan melayani timbulnya dari hati, masing-masing pribadi memiliki jiwa pelayan yang berbeda, kemampuan ini akan timbul disaat ada seseorang yang mampu memberi contoh nyata, sehingga keinginan untuk melayani akan timbul dari hati bukan karna paksaan.

Sosok pelayan yang dimiliki oleh pemimpin, akan mengaspirasi bawahan untuk turut serta mampu melayani dalam sebuah team atau organisasi, penerapan kemampuan pelayan oleh pimpinan disertai dengan pemberian reward, yang bertujuan bukan sekedar pemberian penghargaan, namun nantinya pemimpin ingin anak buah akan mampu sebagai pelayan bukan karena reward melainkan tuntutan alami dari hati.

Penggambaran kebaikan pelayan menurut Arjoon yaitu, harapan menjadi pemimpin yang baik dengan jalan yang sesuai. Mewujudkan harapan tersebut munculnya dari hati seorang pemimpin pelayan yang berlandaskan empati, kepedulian, kemampuan sebagai pendengar yang baik dan komunikasi yang intensif.

\section{Kompetensi Servant Leadership}

Pemimpin memiliki kompetensi dalam memimpin, yaitu tegas dalam membuat keputusan, keputusan yang bersifat mendesak atau terencana, pemimpin yang berintegritas tinggi yaitu pemimpin yang jujur dan dapat dipercaya dapat meningkatkan semangat kinerja karyawanya.

Seorang pemimpin mampu memproyeksikan pandangan kedepan dan memberi motivasi kepada anak buahnya, pemimpin ahli yaitu pribadi yang unggul mampu bernegosiasi dan komunikatif dalam mensinergikan beragam kemampuan anggotanya dan pemimpin yang gigih yaitu pemimpin yang berhasil membawa perubahan dan kemajuan dalam mengejar pencapaian tujuan.

\section{Pengetahuan dan Wawasan}

Wawasan tentang hubungan antarmanusia dengan segala aspeknya juga perlu dimiliki oleh pemimpin dalam rangka pengawasan dan koordinasi. Pemimpin pada kenyataanya memahami hubungan dan karakter manusia, yait para anak buahnya, mereka memiliki potensi dan daya pikir yang berbeda-beda, tidaklah mungkin dapat mengendalikan mereka bila tidak memiliki wawasan tentang hubungannya dengan mereka.

Kunci keberhasilan pemimpin adalah pemahaman terhadap orang lain, mereka dapat memahami orang atau sekelompok orang dan mengetahui aspek-aspek individunya , dengan pemahaman itu pemimpin akan tahu modus apa yang harus dilakukannya agar dapat mengendalikan anak buah untuk mencapai tujuan.

Pengetahuan yang baik yang dimiliki pemimpin akan membuat pemimpin melakukan sesuatu yang baik, membuatnya dianggap lebih/ahli oleh anak buahnya serta mendapat kredensi sosial. Pengetahuan adalah salah satu faktor yang harus dimiliki oleh seseorang pemimpin yang kompeten.

Kompetensi seorang pemimpin dari segi pengetahuan dapat diukur dari beberapa hal: memahami bagaimana mengembangkan dan menggunakan pikirannya dengan baik, tersistem, efektif, dan efisien, dan memahami dengan baik cara berpikir yang menandakan adanya kemauan baik serta semangat untuk maju dan cara berpikir yang menandakan bahwa pemimpin memperhitungkan segala faktor yang terkait dan saling memengaruhi/bekerja sama yang mendukung ke arah keberhasilan. 


\section{Pengalaman}

Kompetensi yang menambah nilai lebih seorang pemimpin yaitu pengalaman, semakin banyak pengalaman yang dimilikinya maka akan semakin baik pula pemimpin dapat menangani segala masalah yang muncul dalam organisasi.

Pengalaman yang dimiliki pemimpin ini bisa saja pengalaman baik atau buruk, yang pasti setiap pengalaman punya manfaat tersendiri yang akan menciptakan keputusan bijaksana.

\section{Ketrampilan Manajemen}

Pemimpin mampu memiliki keterampilan manajemen dalam mengelola anak buah dan organisasinya, ketrampilan manajemen tersebut meliputi:

Keterampilan konseptual, yaitu membuat konsep, ide, dan gagasan demi kemajuan organisasi. Gagasan atau ide tersebut dijabarkan menjadi rencana kerja.

Teknik komunikasi, yaitu keterampilan berinteraksi secara baik dengan banyak orang. Pemimpin yang menunjukan kepada bawahan bersifat mengayomi, persuasif, dan bersahabat, kepada rekan kerja, atasan dan pasien saling menghormati dan bersifat melayani.

Keterampilan teknis, merupakan bekal agar lebih matang pada bidang yang ditangani. Pemimpin mampu dan paham atas pekerjaan yang dilakukan anak buah, agar kerampilan tenknis dan ketrampilan konsep dapat saling bersinergi yang akan menciptakan efektifitas dan efisiensi yang ideal.

\section{Ketrampilan Memimpin}

Keterampilan kepemimpinan dapat berupa program kerja, eksekusi, dan evaluasi diperlukan komitmen, ketegasan, dan keberanian, karenanya pemimpin harus optimis dan tidak terlalu terpengaruh terhadap hal-hal yang tidak perlu. Pemimpin yang kuat akan menciptakan kepercayaan kepada anak buah, sehingga akan memudahkan pendelegasian tugas dan tanggung jawab yang diberikan pemimpin kepada anak buah.

Keterampilan pemimpin mampu sebagai motivator yang baik adalah mampu menentukan titik sentral dan titik awal sebuah langkah akan dimulai. Motivasi akan lahir jika pimpinan menyadari fungsinya sebagai motivator, yaitu memiliki dan menerapkan karakteristik servant leadership.

Ketrampilan pemimpin dalam hal komunikasi, tidak hanya pemimpin yang mampu berinteraksi baik dengan anak buah, namun kemampuan memiliki rasa humor ini akan meningkatkan komunikasi yang intensif antara pemimpin dan anak buah, pemimpin yang mampu memecahkan kebekuan atau ketegangan suasana kerja akan memudahkan interaksi komunikasi, pemimpin yang murah senyum dan mampu menempatkan humor pada situasi yang tepat akan menimbulkan perasaan senang menjalani pekerjaan.

\section{Penerimaan dan Pelaksanaan Servant Leadership}

Pada pendekatan Greenleaf tentang servant leadership, keterlibatan anak buah dalam pekerjaan bertujuan untuk menghilangkan hambatan bagi pertumbuhan anak buah sebagai individu dan peran anak buah. Hal ini akan diperkuat dengan adanya pemimpin yang mampu menjadi asset bagi anak buah untuk dapat konsekuen dalam penerapan karakteristik servant leadership.

Penerimaan servant leadership oleh anak buah menjadikan hal penting untuk kehidupanya, karena penerimaan ini jika sudah menggunakan hati dalam pelaksanaanya, maka karakteristik yang telah ditanamakan oleh Apoteker ke anak buah, akan diterapkan ke lingkungan keluarganya 
tidak hanya dalam lingkungan pekerjaan saja dan nantinya penerapan karakteristik dan kompetensi servant leadership ini akan menjadi kebiasaan yang tidak terlewatkan di kehidupan sehari-hari.

Pelaksanaan dan penerimaan yang telah dilakukan ini dikarenakan sosok pemimpin yaitu pak Bisnis Manager yang mampu mengaspirasi para Apoteker dan Asisten Apoteker untuk menjadi sosok yang berkualitas dalam pekerjaan dan juga hidup, hal ini bertujuan untuk meningkatkan kualitas hidup dan pencapaian tujuan yang lebih baik pada anak buah khususnya dan pada perusahaan pada umunya.

\section{KESIMPULAN DAN SARAN}

\section{Kesimpulan}

Kesimpulan ini akan menjawab tiga pertanyaan penelitian yang diajukan dalam penelitian. Kesimpulan dari dua pertanyaan penelitian tersebut adalah sebagai berikut:

1) Karakteristik servant leadership yang dibangun oleh Apoteker di PT. Kima Farma Unit Bisnis Semarang

Berdasarkan wawancara yang dilakukan membuktikan bahwa servant leadership dengan kasih sayang, pemberdayaan, penyampaian visi, kerendahan hati, mengutamakan orang lain, pelayan dan kepercayaan terbukti sebagai karakteristik servant leadership yang dapat dibangun oleh Apoteker.

Selanjutnya, kasih sayang dan kepedulian dari pimpinan PT. Kimia Farma UB Semarang akan meningkatkan rasa bahagia para bawahan karena bawahan akan merasa lebih dihargai oleh pimpinan dan secara tidak langsung akan menjalankan apa yang diminta oleh pimpinan.

Pemberdayaan dan pelayan yang dimaksudkan dalam hal ini adalah kesempatan yang diberikan oleh pimpinan PT. Kimia Farma UB Semarang terhadap bawahannya. Pimpinan yang memberikan kesempatan besar kepada bawahannya untuk menyampaikan pendapatnya akan membuat bawahan merasa lebih ikhlas untuk menjalankan tugastugasnya karena apa yang ia kerjakan sesuai dengan keinginannya. Penyampaian visi dari pimpinan terhadap bawahan juga sangat berpengaruh, apabila visi yang disampaikan jelas, maka bawahan akan menjalankan tugasnya menuju visi tersebut.

Kepercayaan dari pimpinan terhadap bawahan. Pimpinan yang dapat mempercayai bawahannya akan membuat bawahan lebih bertanggung jawab dalam menyelesaikan pekerjaannya. Bawahan tidak terpaku pada cara pimpinan dalam bekerja namun dapat menyelesaikan pekerjaannya tersebut dengan baik melalui caranya sendiri.

2) Kompetensi servant leadership Apoteker di PT. Kimia Farma Unit Bisnis Semarang

Kompetensi yang dimiliki oleh apoteker, yaitu cara mengimplementasikan gagasan menjadi karya nyata, menjadi apoteker yang mampu berkomunikasi yang baik dengan anak buahnya sehingga anak buah menjadi paham apa yang didelegasikan dan mana yang harus di implementasikan dalam pencapaian tujuan, yang didukung oleh pengetahuan dan wawasan yang luas, pengalaman dan ketrampilan dalam berdiskusi dengan anak buah.

Kompetensi servant leadership ini tidak akan hidup tanpa adanya komunikasi, jadi komunikasi adalah 
jembatan untuk terampil dalam manajemen dan kepemimpinan. Hal ini berkaitan dengan penerimaan anak buah akan penerapan servant leadership yang dimiliki oleh pimpinan.

Peran kepemimpinan servant leadership yang dimiliki oleh apoteker PT. Kimia Farma UB Semarang menunjukkan bahwa hal tersebut dapat meningkatkan kinerja bawahanya. Kepemimpinan yang melayani, mengayomi, memberi kasih sayang dan terciptanya komunikasi yang berkesinambungan kepada bawahannya akan menumbuhkan produktivitas kerja yang tinggi untuk bawahan.

Seorang bawahan akan merasa mudah menyelesaikan masalah pekerjaan dengan didukung pimpinan yang terampil dan menguasai bidang pekerjaan anak buahnya, jadi masalah akan segera teratasi.

3) Penerimaan dan Pelaksanaan Servant Leadership di PT. Kimia Farma Unit Bisnis Semarang

Penerimaan dan pelaksanaan servant leadership yang dilakukan oleh pimpinan kepada anak buah telah terimplementasi dalam lingkungan pekerjaan. Pelaksanaan karakteristik dan kompetensi seorang leader yang mampu mengaspirasi anak buah untuk meningkatkan kualitas pribadi. Penerimaan ini menimbulkan karya nyata yang akan menghasilkan kualitas outlet dengan team yang baik untuk mencapai visi perusahaan.

\section{Saran}

Saran untuk agenda penelitian mendatang berdasarkan penelitian ini, yaitu:

1) Penelitian ini telah membuktikan bahwa karakteristik servant leadership dapat dibangun oleh Apoteker PT. Kimia Farma Unit Bisnis Semarang, untuk penelitian mendatang disarankan dapat melakukan penelitian lanjutan dengan variabel yang sama pada lingkup unit bisnis PT. Kimia Farma yang lain yang memiliki banyak outlet lebih dari outlet unit bisnis semarang, agar mendapatkan sampel yang lebih banyak untuk ruang lingkup yang luas sehingga dapat digeneralisasikan pada organisasi yang lebih besar.

2) Penelitian ini hanya menggunakan salah satu tipe servant leadership sedangkan masih banyak tipe servant leadership lain dengan instrument yang berbedabeda, maka penelitian mendatang dapat menggunakan tipe servant leadership yang lain untuk memperkaya literatur mengenai servant leadership.

\section{DAFTAR PUSTAKA}

Creswell John.W. 2015. Penelitian Kualitatif \& Desain Riset (Memilih Di Antara Lima Pendekatan). Yogyakarta: Pustaka Pelajar

Gibson, 1994, Organisasi: Perilaku, Struktur, dan Proses. Edisi ke 5, Erlangga, Jakarta Greenleaf, R. K, 1977, Servant leadership: A journey into the nature of legitimate power and greatness, Marwah, Paulist Press.

Service, stewardship, spirit, and servant-leadership. Wiley, New York 
---------, 2002, Servant Leadership a Journey into The Nature of Legitimate Power and Greatness, Paulist Press, Marwah New Jersey

Huberman, A.M., \& Miles, M.B. (1994). Data management and analysis methods. Thousand Oaks, CA: Sage

Moleong, J. L, 2010, Metode Penelitian Kualitatif, PT. Remaja Rosdakaya, Bandung

Patterson, K. A.(2003). Servant Leadership: A theoretical model. Dissertation Abstract International, 64 (02),570. (UMI No. 3082719)

Peraturan Pemerintah RI. No. 51. (2009). Pekerjaan Kefarmasian. Jakarta

Sendjaya, S dan Sarros, J. C. 2002. "Servant leadership: Its origin, development, and application in organizations." Journal of Leadership and Organization Studies, Vol. 9, 57- 64

Senjaya, S dan Andi Pekerti, 2010, "Servant leadership as antecedent of trusts in organization", Leadership and Organization Development Journal, Vol. 31, No. 7

Spears, L. C, 2010, "Character and servant leadership: ten characteristics of effective, caring leaders", The Journal of Virtues and Leadership, Vol. 1

Yin, R.K. (2009). Case study research: Design and method (edisi ke-4). Thousand Oaks, CA: Sage 